\title{
Strategic and Tactical Totalization IN THE TOTALITARIAN EPOCH
}

\author{
Adam J MacLeod* \\ Faulkner University, USA
}

\begin{abstract}
This article examines the totalization of private law by public authorities. It compares and contrasts the fate of private law in totalitarian regimes with the role of private law in contemporary, non-totalitarian liberal democracies. It briefly examines the Socialist jurisprudence of the former Soviet Union and its treatment of private law. It offers an explanation why private law might be inimical to the jurisprudence of the Soviet Union and totalitarian regimes more generally. It next examines the totalization of law accomplished by segregationist regimes in the mid-twentieth century, comparing and contrasting those regimes with totalitarian regimes. Then it turns to examine instances of "tactical totalization" in our own day. Examining totalization of law as a jurisprudential, rather than political, phenomenon reveals how the totalization of legal norms can and does occur in liberal democracies, though with substantially different implications than in totalitarian regimes.
\end{abstract}

\section{CONTENTS}

\section{Introduction: Strategic Totalitarianism And Tactical}

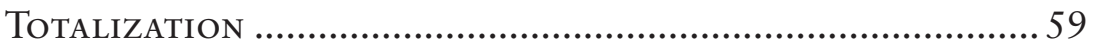

II. The Need for Perfectionist Pluralism in Law .................... 60

A. Law as Exclusionary Reasons for Action............................... 60

B. The Harms of Totalizing Equality …..................................... 64

C. The Possibility and Value of Plural Exclusionary Reasons ... 67

\footnotetext{
* Associate Professor, Faulkner University, Thomas Goode Jones School of Law. I wrote this paper for, and presented an early version at, the public conference, The Totalitarian Epoch: The Fate of Law and Liberty in the $20^{\text {th }}$ Century and Beyond, at Princeton University in May 2014. I am grateful to Robert P. George, Bradford Wilson, and the James Madison Program in American Ideals and Institutions at Princeton University for the invitation. For helpful comments on the paper and/or conversations about the premises articulated in it, I am grateful to Daniel Blomberg, Paul Carrese, Michael DeBoer, Michael DeBow, John Finnis, Matthew J. Franck, Joshua Fullman, John Garman, Jeffrey Hammond, Jason Jewell, Daniel Mark, Robert McFarland, Allen Mendenhall, Michael Moreland, Melissa Moschella, Tina Mufford, Thurston Reynolds, Gabriel Schoenfeld, Ned Swanner, and an anonymous reviewer for the British Journal of American Legal Studies. Thanks also to my research assistant, Caleb Rush, and to Anne Richardson Oakes and the editorial staff of the British Journal of American Legal Studies for their excellent editorial work. The remaining errors are my own.
} 


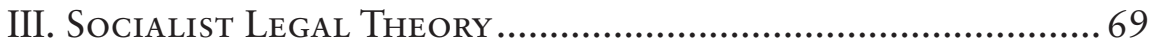

IV. Private Law's Threat to the Totalitarian Project............. 71

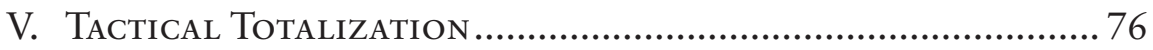

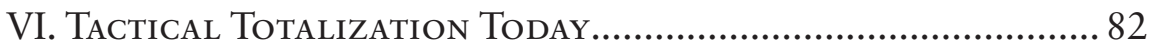

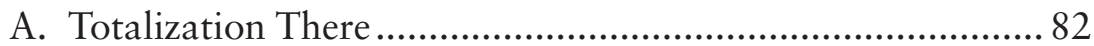

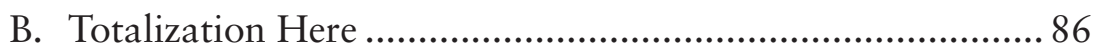

C. Totalization and the Loss of Private Ordering ..................... 91

VII. The Possibility of Pluralism .............................................. 92 


\section{Introduction: STRATEgiC TOTALitARIANism AND TACTICAL TOTALIzATION}

My task is to examine the reach of the totalitarian epoch and its implications for the rule of law. To approach this task, I consider totalitarianism not as a political phenomenon but rather in its narrow jurisprudential aspect, as the totalization by a central authority of the power to settle normative questions that would otherwise be settled by plural authorities. Looking at the matter this way reveals how totalization of legal norms can and does occur in contemporary liberal democracies, though with substantially different implications than in totalitarian dictatorships. The reasons for totalitarianism's antipathy toward private law are shared to a limited extent by political authorities that are not violent or comprehensive in their control of society, but instead exhibit characteristics of what Alexis de Tocqueville termed, "soft despotism," a tyranny that he predicted would be unlike the Roman empire and other ancient tyrannies in that "it would be more widespread and kinder; it would debase men without tormenting them." ${ }^{2}$

Part II of this paper briefly explains why it is important for un-determined and under-determined legal norms to be settled within plural domains, especially domains of private ordering whenever possible (an argument I have made in book length elsewhere ${ }^{3}$ ). Because basic human goods are incommensurable and affirmative responsibilities are open-ended, most duties of abstention and all affirmative obligations are un- or under-determined by reason. The act of settling and specifying those duties and their correlative liberties and rights is a reflexive act, which has moral value for the groups and communities that perform it, as it forms identity in the order of the will. The liberty to deliberate, choose, and specify norms within domains of private ordering is therefore an indispensable condition of developing one's ability to realize the distinctly human good of practical reasonableness.

This account of norms entails a perfectionist commitment to plural domains of authority (and thus it is not libertarian or individualist), which requires that those domains enjoy liberty (and thus it is not left-liberal or statist). This is a contemporary defense of a classical, common-law sense of liberty. This part also examines the harm caused by totalizing norms of equality and non-discrimination. All law is discrimination, and the plurality of goods and of private ordering requires that discrimination be allowed for valid reasons and forbidden when the reasons are never to be considered in the circumstances. Because norms of equality and non-discrimination

1 Alexis de Tocqueville, Democracy in America 803-09 (Gerald E. Bevan trans., Penguin 2003) (1835).

2 Id. at 804.

3 Adam J. Macleod, Property and Practical Reason (2015). 
are under-determined in the abstract, they can seldom justifiably be used to eliminate norms and judgments of private law.

The clearest case of totalization of norms is of course to be found in a totalitarian regime. Among such regimes, the Soviets are interesting for having developed a jurisprudence to explain their totalizing ambitions. Soviet socialist jurisprudence thus serves as a focal case of the phenomenon examined here. To get a sense of the incompatibility between totalitarian jurisprudence and private law, Part III briefly examines the Socialist jurisprudence that was ascendant within the former Soviet Union and its proxies and allies, particularly its treatment of private law.

The study then generalizes a bit to consider whether totalitarian rule is necessarily hostile to private law and private ordering. Part IV of this article suggests why private law poses a threat to governing regimes that aspire to total control of the political community. It also explores how totalization of law can be viewed in its jurisprudential aspect, apart from the violent barbarities that totalitarian regimes committed in the twentieth century.

A general jurisprudence of totalization enables one to perceive totalization of legal norms in non-totalitarian societies. The latter parts of the paper examine attempts at totalization of law that have arisen within liberal democracies. Part V examines the use of tactical totalization of law within states that aspired in the twentieth century to attain complete segregation of races. Part VI points out some places where tactical totalization appears in liberal democracies and liberalizing societies today.

Part VII briefly considers the prospects for a principled pluralism that might resist totalization and promote human flourishing. Those prospects are not possible under a totalitarian regime but are available in a society that preserves the forms and institutions of liberty despite the tactical totalization of private law norms. Liberal democracies are quite radically different from totalitarian regimes in this sense (among others). This suggests that security for liberty can be regained in liberal democracies by reinvigorating the cultural practices and institutions of private ordering and private law-making.

\section{The Need for Perfectionist Pluralism in Law}

\section{A. LaW as Exclusionary Reasons fOr Action}

Law in its broadest sense consists of authoritative settlements of practical inquiries for the purpose of directing the actions of agents who respond to reasons. Law can direct the choice and action of an individual as a reason for her action as she brings her choices and actions into line with determi- 
nate laws, understood as sources of obligation. ${ }^{4}$ Law can also act normatively upon the deliberations and actions of groups and associations of individuals. It can direct and coordinate actions among members of a group, association, or community by providing a reason for action that is settled and specified to promote the pursuit of a common good, a good that is common to the members of the group. ${ }^{5}$

These settlements take the form of reasons of a particular kind, which is determinate and does not leave deliberation and choice open. With H. L. A. Hart we might examine these reasons in their form as rules, which supply authoritative, content-independent, and peremptory reasons for action. ${ }^{6}$ Or with Blackstone we might note that a rule of action is called a rule "to distinguish it from advice or counsel, which we are at liberty to follow or not, as we see proper, and to judge upon the reasonableness or unreasonableness of the thing advised." 7 We might speak of determinate legal reasons as Grégoire Webber speaks of rights, as absolute or conclusive reasons for action. ${ }^{8}$ Or with Joseph Raz we might treat a determinate legal reason as a type of secondary reason for action called an "exclusionary" reason."

The idea common to all those accounts is that legal reasons foreclose further deliberation about the particular practical inquiry at issue. In their focal sense, determinate legal reasons block out of deliberation-forbid further consideration of-other possible reasons. They are, in short, reasons "for excluding normal free deliberation about the merits of" doing or not doing an action. ${ }^{10}$

For present purposes it will be most fruitful to follow Raz's expression of the idea of a binding norm as an exclusionary reason for action. Once settled and specified, the legal reason requires one to exclude from one's future deliberations the first-order reasons that might otherwise have weighed for or against the action that is now required or forbidden. To perform this work, exclusionary reasons must be settled as authoritative by someone. Some require little or even no specification. Insofar as there are exceptionless moral norms, ${ }^{11}$ some normative reasons are fully determined, or nearly so, before their settlement and specification in law. Because one can never be reasonably justified in maiming, enslaving, or raping another human being, one has exceptionless duties not to maim, not to enslave, and not to rape anyone.

4 H. L. A. Hart, The Concept of Law 89-90 (2d ed. 1994).

5 John Finnis, Natural LaW and Natural Rights (2d ed. 2011) at ch. VI through X.

6 H. L. A. Hart, Essays on Bentham (1983) at ch. 10.

1 William Blackstone, Commentaries on the Laws of England 44 (1769).

8 Grégoire Webber, The Negotiable Constitution: On the Limitation of Rights (2009) at ch. 4.

9 Joseph Raz, The Morality of Freedom (1986) [hereinafter Raz, Freedom] at Ch. 7; JoSeph Raz, Practical Reason and Norms 35-48, 73-89 (1999) [hereinafter Raz, Norms]; Joseph Raz, Practical Reasoning 128-43 (1978).

10 HART, supra note 6, at 255.

11 John Finnis, Moral Absolutes: Tradition, Revision, and Truth (1991). 
Those exceptionless duties, being duties owed to all human beings, correlate with and give rise to: the absolute liberties of all human beings not to be maimed, enslaved, and raped; claim-rights against anyone who maims, enslaves, or rapes; immunities from the loss of one's absolute liberties and claims rights; and duties and powers in political communities and their officials to secure and enforce all those rights and duties. Some of those norms require some additional specification. For example, there is not obviously one uniquely-right answer to the question what the criminal punishment should be for maiming. Nevertheless, a duty not to maim, enslave, or rape and the correlative rights are, in common law terms, declared by the lawmaking sovereign, rather than settled and specified by it; ${ }^{12}$ they existed as conclusive norms before their declaration and their declaration in human-made law is not the source of their authoritativeness. To the extent that positive law is to be consonant with reason, these fundamental duties and rights cannot be ignored or abrogated.

Yet the vast majority of exclusionary reasons are either undetermined or under-determined unless and until they are specified by some authority. Rights are absolute when they correlate with absolute duties. And a duty can be absolute and exceptionless only if it is a duty of abstention. John Finnis has explained,
Where these duties are negative duties of respect-duties not to inten- tionally damage or destroy persons in basic aspects of their flourishing- they can be unconditional and exceptionless: "absolute rights." Where they are affirmative responsibilities to promote well-being, they must inevitably be conditional, relative, defeasible, and prioritized by rational criteria of responsibility such as parenthood, promise, inter-dependence, compensation and restitution, and so forth. ${ }^{13}$

In many instances, moral and pragmatic considerations will not determine an affirmative duty, or not determine it fully, because specification requires an ordering of competing goods-alternative possibilities that possess intrinsic, intelligible value but which cannot all be pursued because of limitations of time, resources, abilities, and other human limitations-and those goods will not be measurable against each other on any common scale of measurement. Basic goods are incommensurable. ${ }^{14}$ And therefore the goods chosen and pursued by one individual or group are not always, or even often, commensurable with the goods and plans of other individuals and groups. Responsibilities to pursue or instantiate basic goods are either rationally under-determined or entirely undetermined. It is the choice of one

121 Blackstone, supra note 7, at 42, 54.

13 John Finnis, The Priority of Persons Revisited, 58 Am. J. Juris. 45, 53 (2013)., MacLeod, supra note 3 , at Chs. 7 and 8.

14 See generally Raz, Freedom, supra note 9, at 145-46, 279-84; Finnis, supra note 5, at Chs. III, IV, and V. 
exclusionary reason over alternative, possible reasons that renders them obligatory and binding.

This is one reason why many (though not all) exclusionary reasons differ from individual to individual, group to group, community to community: many first-order reasons are incommensurable with each other. Different groups and communities of people have their own first-order reasons for action-the health of one's family, the success of one's business partnership, the safety of this neighborhood, the acquisition of knowledge within that school or a particular profession, their assembling together to worship according to their creed (rather than ours), the feeding of the homeless in one's city, the redress of that wrong by this civil jury-that are not shared by the entire political community. The common good of the entire community as a whole does not exhaust the common goods of all of the individuals and communities within its jurisdiction. Groups and communities of people have goods that are common to their members that are incommensurable with-not measurable against or reducible to-the common good of the political community as a whole.

The goods of these groups and communities can reasonably be settled in a wide variety of plans and sub-plans, exclusionary reasons that bind a group's members and coordinate their actions toward realization of the group's common good, as opposed to some other good. And many plans and commitments can be constituted in various reasonable specifications. This is another reason why affirmative rights and duties are left rationally un- or under-determined by considerations of morality, justice, and prudence. Yes, I have a responsibility to educate my children. But is that duty satisfied by sending them to this school, or must I send them to that one? Is it wrong to educate them at home, or to hire a tutor? If a child is not academic in his interests and abilities, can I not reasonably enroll him in a trade school? The duty must be specified in context after consideration of many different facts and goods.

Even some duties of abstention are not absolute. Categorical, exclusionary reasons for action are those that block out of deliberation-foreclose consideration of as possible justifications for action-discrete categories of potential reasons, or all reasons but those in a discrete category or categories. For example, the duty to exclude oneself from others' property is overridden when entry is necessary to save a human life, to execute legal process, or to meet some other strict necessity, but is otherwise absolute. ${ }^{15}$ The correlative property right to exclude is therefore categorical but not

153 BlaCKSTONE, supra note 7, at 212-13. On categorical-but-not-absolute exclusionary reasons for action, in property law and generally in private law, see MacLeod, supra note 3, at Chs. 7, 8. Raz admonishes, "It should be remembered that exclusionary reasons may vary in scope; they may exclude all or only some of the reasons which apply to certain practical problems." RAz, Norms, supra note 9, at 40. I propose that such exclusionary reasons can be understood as legal reasons (rights and duties), though they are not fully exclusionary, when they exclude from deliberation and choice discrete categories of first-order reasons. 
absolute. Other duties are absolute and fully-determined but require remedies and sanctions to render them enforceable, which might not always be determined. For example, there is not necessarily one uniquely-correct answer to the question what should be the punishment for human trafficking.

\section{B. The Harms of Totalizing Equality}

Responsibilities of equality, non-discrimination, and universalizability of concern are among those norms that are undetermined and under-determined in the abstract. ${ }^{16}$ Generalizations about equality seldom hold in all, or even most, cases. Discrimination is not an intrinsically good or right action, but nor is it intrinsically bad or wrong. Like all exclusionary reasons for action, laws discriminate. Insofar as many laws and judgments are good and just, much discrimination is good and just; insofar as some laws and judgments are evil or unjust, some discrimination is evil or unjust.

Discrimination is a fact of reasoning. The act of making law-indeed, every act of practical judgment-is discriminatory because choosing and specifying exclusionary reasons for action is a matter of ruling out potential reasons for action as not to be acted upon and privileging and committing oneself to those reasons for which one will act. That discrimination, lawmaking, and judgment sometimes go wrong does not lessen the need for discrimination, law-making, and judgment. Those actions, when done well, are not only valuable but in many instances strictly necessary.

Law discriminates; reasoned deliberation discriminates; judgment discriminates. The question in each case is whether discrimination is justified on the basis of reasons, and therefore reasonable discrimination, or instead lacking in reasoned justification because motivated solely by fear, prejudice, passion, or other non-rational sources of partiality. It seems non-controversial, for example, that racial discrimination requires some justification, which generally must be compelling and proportionate. ${ }^{17}$ It is equally uncontroversial (for now, perhaps) that discrimination on the basis of marital status is reasonable for many purposes, such as enforcing the presumption of paternity and determining eligibility to marry.

And acts of discrimination, law-making, and judgment are not only strictly necessary, they are also valuable. Discrimination cannot be elimi-

16 What follows draws heavily upon HART, supra note4, at Ch. VIII; John Finnis, Equality and Differences, 56 Aм. J. JuRIs. 17 (2011); and Sherif Girgis, Equality and Moral Worth in Natural-Law Ethics and Beyond, 59 Aм. J. JurIs. 143 (2014).

17 The Supreme Court of the United States has ruled that racial discrimination is justified on a strict-scrutiny, ends-means analysis when used to reverse the legacy of previous de iure discrimination or to achieve diversity in an elite law school: Grutter v. Bollinger, 539 U.S. 306 (2003). Cf. the United Kingdom's Equality Act 2010, allowing proportionate, direct discrimination to remedy various inequalities and requiring direct discrimination where it is necessary to overcome indirect discrimination; "positive action" is justified direct discrimination. See Finnis, supra note 16, at 31-35. 
nated for the sake of pure equality without injuring essential aspects of human well-being, which require practical reason and practically-reasonable judgment to bring them about and to sustain them. To posit equality as an absolute (or even categorical) norm is to eradicate the possibility of reasoning rightly, for the common good. As John Finnis expresses it, to "act without discrimination" is to act "without good judgment, indiscriminately." 18

Equality cannot justify overriding norms and judgments of difference because it is not a justification in itself-an intrinsic good or a basic moral requirement-for any law or judgment. ${ }^{19}$ To put the matter pointedly, the norm requiring equal treatment and the norm against discrimination are nothing like the absolute duties one has not to maim, enslave and rape anyone. They are anything but universal, absolute, fully-conclusive norms.

Human beings are alike in some characteristics and unlike in others; some considerations are so peripheral as to be irrelevant and others are essential. Without an informed and accurate determination which characteristics are relevant, "Treat like cases alike' must remain an empty form," and Hart has therefore suggested that justice consists of "two parts: a uniform or constant feature, summarized in the precept 'Treat like cases alike' and a shifting or varying criterion used in determining when, for any given purpose, cases are alike or different." ${ }^{20}$ The empty form must be filled with reasons-reasons for and against acting on the basis of a distinction, and reasons for discriminating between and evaluating those reasons that weigh for and against differential treatment. The job of practical deliberation is to consider the reasons to determine whether equality or inequality is warranted in each case.

Thus, equality or inequality is a conclusion, not a premise, of practical deliberation and judgment. Until one considers the reasons for and against different treatment one cannot say whether equal or unequal treatment is warranted. In this calculation, as compared with difference, equality is no greater or lesser reason for action. The norm of justice is a norm of equality and inequality, that like cases should be treated alike and different cases differently.

Sherif Girgis has argued that this means there is no moral default in favor of equality as against difference. Instead,

the true moral default is not equal treatment but reason-based treatment, or non-arbitrary treatment-which itself favors neither sameness nor difference of treatment. Our reasons for giving some good to one party are either the same as our reasons for giving it to every other party, or they are different. If the same, then it would be arbitrary to treat the parties unequally: respect requires treating them equally, and dividing the good accordingly. If different, then it would be arbitrary to treat them equal$l y$ : respect requires treating them (i.e., distributing the good) unequally.

18 Finnis, supra note 16 , at 27.

19 Girgis, supra note 16, at 146-49.

20 HART, supra note 4, at 159. 
There is no more of a presumption of equal than of unequal treatment. Indeed, we might as well have a Principle of Differentiation, to match the principle of equality: there is a presumption of differential treatmentexcept where the reasons bearing on potential beneficiaries of our action happen to be the same, and then we treat them equally. ${ }^{21}$

Girgis concludes, "There is thus no neutral case in which a presumption of moral equality adds a point to break a putative $0-0$ tie in favor of equal (as opposed to unequal) treatment of two parties. That would mean no reasons were at stake; yet intentional action is always for reasons." 22

Equality as an absolute norm threatens those reasons. Non-discrimination laws achieve their objectives by eliminating from deliberation, judgment, and choice, possible reasons for action that are deemed not relevant considerations in the context identified. As Finnis explains, the point of laws prohibiting direct discrimination is "to banish protected characteristics from decision-makers' deliberations; the rationale's presupposition is that they are irrelevant, and that decision-makers considering personal characteristics can therefore be rightly required to focus exclusively on such characteristics as are relevant to the task in hand." 23

The danger here is manifest. If a universal law of general application banishes from deliberation and judgment a consideration that is not irrelevant, but is instead an essential aspect of a valuable and reasonable plan of action or life plan, then the law has eliminated from society a valuable and reasonable plan of action or life plan. The more sweeping non-discrimination laws become, the more considerations they banish from deliberation, and the less likely those considerations are to be per se always irrelevant, the more likely they are to cause this destruction. Race is quite safely and reasonably banished. But when non-discrimination laws start to prohibit consideration of sometimes-relevant considerations such as language, political party membership, national origin, and so forth, those laws jeopardize the plans or even identities of individuals, families, groups, and associations that are constituted around such characteristics. Consider, for example, a Hispanic Law Students Association.

Even accommodations or exemptions from non-discrimination laws can (perversely) contribute to the problem, even as they are offered as forms of mitigation. For to give reasons of difference a secondary role of deliberation, to treat differences as if they are exceptions to a general rule of sameness, is to obscure the plurality and incommensurability of plans and norms within society and to distort and even suppress important human goods and requirements of justice, such as the unique value of natural mar-

21 Girgis, supra note 16, at 153 (emphasis in original).

22 Id.

23 Finnis, supra note 16, at 31. 
riage, the well-being of children, obedience to conscience, merit and desert, and much else. ${ }^{24}$

Totalization of the norms of difference by a central power inevitably treats cases that are relevantly different as if they were the same. Uniform rules of general application can be neither uniform nor general if they are to take into account every textured feature of practical reason's operation in society. In our egalitarian age norms of equality and non-discrimination seem especially prone toward this danger. Equal treatment is certainly an important consideration and a worthy goal when it is warranted but not when it banishes from deliberation other worthy considerations and goals, such as meritorious treatment, proportionate distribution, integrity with prior judgments, and all of the other aspects of justice, not to mention all of the other human goods that can be pursued in society only if individuals and groups have freedom to pursue them.

Contemporary equality architects seem to be simply unmindful of those considerations, and seem to pay little attention to the instantiation of those distinctions in private law. They would do well to pay better attention. A side effect of the over-pursuit of equality and non-discrimination is, as John Finnis observes, a "negative impact on established constitutional rights such as freedom of association, freedom of religion and conscience... a negative impact which in each case involves also a very substantial shrinking, or invasion, of private life by coercive law." ${ }^{25}$ That is a significant loss, as the next section explains.

\section{The Possibility and Value of Plural Exclusionary Reasons}

This broad, perfectionist conception of law as exclusionary reason directing action toward a specific good or goods makes it possible to perceive the law-ness of private law without reducing private law to absolute, individual rights. Private and non-state civic groups need to coordinate their actions in order to achieve their common goods, just as wholesale political communities do. A private group's first-order reasons for acting or refraining from acting-human goods, requirements of practical reasonableness (those requirements that are today called morality and in the common law tradition are often referred to as natural law or the law of nature), conscience, local and general customs - must be specified as authoritative, exclusionary reasons for action if the community is to coordinate the actions of its members. This can be done only in one of two channels, either (1) in unanimity or a close approximation of unanimity, such as custom or agreement, or (2) by some authoritative promulgation. ${ }^{26}$ Someone must choose, either the entire group or someone who exercises (not un)lawful authority on the group's behalf.

24 Finnis, supra note 16, at 40.

25 Finnis, supra note 16, at 36.

26 FinNIs, supra note 5, at 231-54. 
In instances where the norm was un- or under-determined prior to its specification, the act of settling and specifying the norm is what brings the norm into being. And when an individual or private group or association specifies its norms it constitutes more than merely its rights and duties. It also constitutes itself. It makes itself in what Thomas Aquinas identified as the order one establishes in the operation of the will. ${ }^{27} \mathrm{~A}$ person or group of persons who chooses a plan, a commitment, an obligation, make themselves into the kind of being who privileges and values that plan, commitment, or obligation as against other possibilities. ${ }^{28}$

The act is one of adopting exclusionary reasons that exclude various possible first-order reasons. By excluding from future deliberations those reasons for which the person or group will not in the future act (even, or perhaps especially, if others will), the person or group becomes not the person or group who acts for those excluded reasons. A university constitutes itself within its domain by not choosing to be a commercial retail outlet or a pharmaceutical manufacturer. A liberal arts university constitutes itself by not choosing to be a trade school or institute of science and engineering.

So, the institution is constituted in part by the first-order reasons it does not choose to pursue. It is constituted even more clearly by the firstorder reasons it chooses not to pursue. One university, Vanderbilt, constitutes itself as a university that excludes student groups which insist upon following Christian and Orthodox Jewish ethical commitments. ${ }^{29}$ Another educational institution, Gordon College, constitutes itself as a Christian institution whose members must agree not to perform actions that violate Christian ethical norms. ${ }^{30}$ The identities of those institutions are constituted in part by the first-order reasons for action they will not allow to be acted upon on their campuses. The act of ruling out first-order reasons that will be excluded focuses one's attention upon and anneals one's commitment to those reasons that are chosen. And by choosing to obligate oneself to act for the reasons for which the person or group will act, the person or group constructs a will oriented toward those reasons. This person or group is this person or group, and not some other, because of the exclusionary reasons that constitute the person's or group's identity. Those commitments are laws, nonetheless constitutional laws for being private laws. ${ }^{31}$

27 Thomas Aquinas, Commentary on Aristotle's Nicomachean Ethics 1-2 (C. J. Litzinger trans., Dumb Ox 1993). Compare RAz, Freedom, supra note 9, at Ch. 14; AMartya Sen, Development as Freedom (1999).

28 John Finnis, Collected Essays of John Finnis, vol. II: Intention \& Identity 36-68 (2012).

29 Michael Stokes Paulsen, Vanderbilt's Right to Despise Christianity, PuB. Discourse (Mar. 14, 2012) http://www.thepublicdiscourse.com/2012/03/4930/.

30 Adam J. MacLeod, Gordon College and Pluralism in Higher Education, Pub. Discourse (July 30, 2014) available at http://www.thepublicdiscourse.com/2014/07/13600/.

31 Adam J. MacLeod, Universities as Constitutional Lawmakers, 17 U. PA. J. Const. L. ONLINE 1 (2014). 


\section{Socialist Legal Theory}

One gets the sense that private law was not a primary concern in Soviet socialist legal theory. Unlike the consolidation of political power, which required the complete instrumentalization of public law, collectivization required centralized control of productive resources. It was primarily an economic project focused on control of the resources themselves rather than the norms governing their use and management. ${ }^{32}$ Yet the norms of private law are specified as incidents of, and by the authority exercised in, the power to control. Who has dominion has the authority to make law within the domain. And so private law is not excluded from the twin Socialist critiques of law generally, which assert (as Lon Fuller summarized them) that "(1) law and the state are a superstructure reflecting the basic economic organization of society, and (2) in the socialist economy of the future, both law and the state will "wither away." "33 Early Socialist jurisprudence seems to have taken for granted that private law, like all law, would disappear as capitalism disappeared. It would be unnecessary under a regime of centrally-planned production and association. ${ }^{34}$

When it appears in early socialist jurisprudence, private law is portrayed as abstract and artificial. Evgeny Pashukanis, whom Fuller titled "the leading jurist of Russia," 35 adopted Marx's Hegelian view of property ownership, in which property becomes owned when the owner's will is placed into the thing. On this foundation he built a characterization of private law as formal and abstract. Ownership and the rules and incidents that attach to it are legal forms originating in competitive trade and designed to distinguish subject from object in order to make commercial exchange possible. The rights and duties of property and private law are abstract forms designed to create artificial categories of individual rights and responsibility. ${ }^{36}$

So, early Socialist legal thought treated private law as a servant of capitalism, created by capitalist logic to serve capitalist ends, and therefore an impediment to emancipation. Among capitalism's instruments of repression, the Socialist legal theorist identified property and contract as playing particularly instrumental roles. Private law establishes the foundation for rights and duties borne by individuals, enables contractual exchange in the market, and is therefore required for commerce among independent actors. Private law is unnecessary under a totalizing regime of planned production

32 See John N. Hazard, The Soviet Legal Pattern Spreads Abroad in Law in THE Soviet Society 277, 287-92 (Wayne R. LaFave ed, 1965).

33 Lon Fuller, A Study in the Development of Marxian Legal Theory, 47 Mich. L. Rev. 1157, 1159 (1949).

34 Martin Krygier, Marxism and the Rule of Law: Reflections After the Collapse of Communism, 15 LaW \& Social Inquiry 633, 654-56 (1990).

35 Fuller, supra note 33, at 1159.

36 Evgeny Pashukanis, The General Theory of Law and Marxism (Barbara Einhorn trans., Transaction 2002). 
and association. ${ }^{37}$ And its forms are ultimately illusory. As Arthur Ripstein observes, for Pashukanis, private law's forms of agency, responsibility, and formal equality misrepresent the reality that "the choices for which agents are responsible are themselves shaped by the market." ${ }^{38}$ The vision was that, when conflicting individual purposes were abolished, private law would be rendered obsolete and wither away.

Yet as long as it remains, private law is inimical to central planning because in the course of enabling capitalism it substitutes for the comprehensive plan so essential to communism's success, it maintains the artificial forms of individualism, and thus it impedes the emancipation that Communism promises to deliver. Private law's presumptions of individual subject, individual and group agency, and private interest are inconsistent with the comprehensive plan of the unified mind ${ }^{39}$ with its unitary good and singular means.

The central, unified mind directing the operation of law seems to have played a significant role in later Socialist jurisprudence, as law was accepted and turned toward the Party's ends. ${ }^{40}$ Unlike Pashukanis, for whom Socialist law was still law, and therefore fundamentally bourgeois, later Socialist jurisprudents made their peace with the idea of law. ${ }^{41}$ In that later Socialist jurisprudence, the whole of Soviet law is a single organic being, comprised of soul and body governed by a single reason and will. ${ }^{42}$ Its parts have no minds of their own; they do not deliberate and render judgments. So, for example, in the Soviet model of planned contracts, "the will of an administrative planning agency" substituted for "the will of the contract partners." 43

The central mind-the Party-was "the brain, the conscience, the mind of the Soviet society." The Party was the one "self-perpetuating organization." Private action poses no threat to the totalitarian project as long as that action is directed by norms specified by the central mind, but it is a threat if directed by the reasoned deliberations and judgments of the independent moral agents. Thus, use of land was assigned to private individuals and groups in Soviet society, and even some personal property rights, but not the authority to specify the rights and duties of property ownership by powers of exclusion, alienation, mortgage, or donation. ${ }^{44}$

For the same reason, there are no rights in Socialist jurisprudence, only concessions of privileges that the sovereign may freely revoke. Indeed, citi-

37 Krygier, supra note 34, at 654-56.

38 Arthur Ripstein, Equality, Responsibility, and Law 253 (1999).

39 Krygier, supra note 34, at 635.

40 I am indebted to Michael DeBow for this observation.

41 Fuller, supra note 33, at 1163-64; Dietrich A. Loeber, Plan and Contract Performance in Soviet Law in Law In the Soviet Society 128, 176-79 (Wayne R. LaFave ed, 1965).

42 Christopher Osakwe, The Four Images of Soviet Law: A Philosophical Analysis of the Soviet Legal System, 21 Tex. INT'L. L. J. 1, 2 (1985).

43 Loeber, supra note 41, at 129.

44 Osakwe, supra note 42 , at $15-18$ \& n.33. 
zens are property of the state, and "the dominion of the sovereign over all members of the society is absolute." ${ }^{45}$ Dominion entails authority to settle norms - rights and duties-for those within the domain. Plural domains, or even a government whose powers are separated among different branches or federal sovereigns, can specify legal norms that bind both the governed and those who exercise authority. But rights and duties are juristic concepts attaching to legal subjects, which are forms peculiar to capitalism. By contrast, the unitary sovereign, directed by the unified mind, has no need of rights and duties. This unitary sovereign from which all rights emanate as concessions of privilege is not bound by its own law, nor by anyone else's.

\section{Private Law's Threat to the Totalitarian Project}

That is merely one totalitarian legal theory, although arguably the world's most influential to date. Perhaps the antipathy of Socialist jurisprudence toward private law is (ironically) historically contingent. Is there a necessary incompatibility between private law and totalitarian legal thought?

The argument for the affirmative is straightforward. Private law is inimical to totalitarian rule because and to the extent that it is inimical to central planning, which requires a unity of end(s) and a single, comprehensive plan for its/their attainment. The existence of private law suggests plural ends and means of ordering, and therefore suggests plural instantiations of lawfulness.

On the other hand, this plurality of orders within private law might suggest that private law is not law in fact, and therefore not a rival to the rule of a unitary lawgiver. Private law does not share public law's ambition to provide, as John Finnis has characterized the end of public law, "comprehensive and supreme direction for human behaviour" 46 in the political community as a whole. It does not claim to be the source of validity of other normative arrangements, and it seldom resorts to coercion. It does not often even attempt to supply conclusive reasons for action ex ante.

If private law does not entail universal rules of general application, if many of its doctrines are indeterminate and specified only in particular legal judgments, if it is not publicly promulgated ex ante, and if it is not backed by coercion or threat of coercive sanction, then private law might not partake of the nature of law. In these and other respects, private law does not always, or even often, exhibit those attributes without which, Lon Fuller influentially argued, a law cannot be a law. ${ }^{47}$ Private law might lack

45 Osakwe, supra note 42, at 18.

46 Finnis, supra note 5, at 260.

47 Lon L. Fuller, The Morality of Law (1964). 
law's indispensable inner morality. If that is true then the ends and means of public law might exhaust the ends and means of law.

Yet for those who employ private law (i.e. everyone who lives in a jurisdiction in which private law is permitted), these facts about private law are considered strengths, not failings. Thus, there is at least as much reason to interrogate the employment of public law rules as focal instances of law as there is to doubt the law-ness of private law. Benjamin Zipursky points out that Fuller's view understands law as "a system of governance that works by consolidating authority in the state, which issues enforceable rules of conduct and has the power to enforce those rules of conduct by sanctioning those who fail to comply with them." 48 Private law cannot be understood so simply. It functions by responding to the nearly-infinite varieties of acts of private ordering, and therefore must provide many different settlements to various inquiries. A conception of law that takes public law as its defining instance or focal case might not capture the complexities of private, legal ordering.

Zipursky and Ernest Weinrib are among those who have noticed that private law has its own inner logic, which is not reducible to its instrumental utility for attaining collective ends. ${ }^{49}$ This suggests that private law is authoritative, but in a different way than public law. Not all of it is concerned with governance. Some private law (e.g. condominium bylaws or university nondiscrimination policies) mimics pubic law. But other areas of private law are concerned with specifying private rights and duties, e.g. property, ${ }^{50}$ empowering those harmed by wrongful conduct to obtain redress, e.g. torts ${ }^{51}$ and remedies, and other purposes that are not reducible to governance, e.g. contracts, trusts and estates, and commercial law. Thus Hanoch Dagan has argued that "monist theories can hardly account for the vast heterogeneity of our private law doctrines." 52

To develop a complete account of the domains of private and public law and the boundaries between them is beyond the scope of this article. For present purposes focal cases must suffice. That the norms of private domains are specified and treated as authoritative within the domains of private ordering means that private law is possible. ${ }^{53}$ That private law does act authoritatively within its own domains is a factual matter open to observation. There are hard questions at the boundary between public and private law but there are also focal cases of each. A local custom, a bailment, a church bylaw, and a contract are all private laws. A handgun or

48 Benjamin C. Zipursky, The Inner Morality of Private Law, 58 Am. J. JuRIs. 27, 36 (2013).

49 Zipursky, supra note 48; Ernest Weinrib, The Idea of Private Law (2012).

50 See the essays in Philosophical Foundations of Property Law (James Penner \& Henry E. Smith eds., 2013), MacLeOD, supra note 3.

51 Zipursky, supra note 48, at 39-40.

52 Hanoch Dagan, Pluralism and Perfectionism in Private Law, 112 Colum. L. Rev. 1409, 1411 (2012).

53 See Adam J. MacLeod, Private Rights and Duties, 6 FAulKner L. Rev. 65 (2014). 
marijuana ban, backed by threat of criminal sanction, is a focal example of a public law. Private law often provides for and depends upon reasoned deliberation about what to do within particular communities and specific contexts; in its focal sense, public law does not.

One should hasten to note that, just as it would be a mistake to view private law as defective public law, one could go wrong by viewing public law as merely a security against the failings of private ordering. It is sometimes necessary and justified for a political community to work according to a unitary plan of action for discrete times or discrete ends, as where a central authority is waging a defensive war against an enemy bent on the society's destruction. Nor should all law be private law. There are some absolute and categorical norms without which no society can flourish-as observed above, one must never maim, enslave, or rape. And these norms must in justice be specified not only as private rights and duties-rights of bodily integrity, liberty, exclusion, etc.; duties not to kill, enslave, or take without permission-but also as ex ante prohibitions, promulgated as clear rules and backed by threat of criminal sanction. And sometimes it is necessary for the political community to promulgate malum prohibitum offenses in order to achieve particular goods by discrete plans of action-protection of streams and rivers from pollutants, the timely and safe delivery of the mail, etc. Furthermore, those entrusted with the authority to enforce these rules and mete out the sanctions must themselves be controlled by rules, lest they abuse their power. So, we have constitutions.

Nevertheless, many rights and duties cannot reasonably be specified except within particular contexts, and upon particular judgments of reasonableness. And someone must perform the authoritative specifying. Institutions and authorities of private ordering fill this need. And this is why private law is necessarily at odds with totalitarian rule. For a governing elite to be totalitarian, and not merely thuggish, it must establish a monopoly on judgments of practical reason. It must become the only source of exclusionary reasons for action. To the extent that people look to other sources of authority when deciding what they should and should not do, the central plan is not commanding total obedience.

A measure of a regime's success in establishing totalitarian rule will be how effectively it displaces private law. The existence of private law is an indication that the central authority is not the only domain of deliberation and judgment within the society, and therefore the central plan is not in fact unified and comprehensive. Institutions of private ordering must be deprived of either their freedom or authority (or both) to engage in meaningful practical deliberations.

That is the external conflict between the central plan and private law. There are at least two additional reasons why private law is anathema to totalitarian rule, both related to the reflexive, internal aspects of private ordering. First, totalitarian governments cannot let freethinking citizens and institutions flex their practical-reasoning muscles on questions of civic importance. To defer to the reasoned judgments contained in private law is to trust one's fellow citizens to become capable of exercising authority over 
their own affairs. So, totalitarian governments must eradicate opportunities for private citizens to reason and to govern their own affairs.

Normative ordering is a self-constituting activity in the sense of being will-ordering, which is habit-forming, and therefore character-forming. The exercise of practical reason, including the specification of authoritative reasons for one's own conduct and the plans and actions of one's groups and associations, is a reflexive (self-constituting, architectonic) exercise. ${ }^{54}$ The more one does it, the more accustomed one becomes to doing it, and the better one may become at it. The act of normative ordering makes mature and wise citizens out of puerile and incompetent ones. This exercise brings about liberation, not from nature and material circumstances, but rather from servility and enslavement to the passions. Totalitarianism cannot long last when citizens are free and able to think and choose for themselves.

Second, private ordering is a self-constituting activity in the sense that, by selecting exclusionary reasons from possible alternatives, an individual, group, or community commits itself to those reasons and not other reasons. By deliberating and choosing, individual and group agents make for themselves new obligations and other reasons for action, which may be inconsistent with what the central authorities would choose for them. They commit themselves to ends and means that others might not value or appreciate, and they constitute their identities around those ends and means in the order of the will. ${ }^{55}$

The very idea of private law presupposes that there are domains within which one may exercise practical judgment and free choice in ordering one's affairs, either by oneself or with other moral agents, for common ends. So, the incompatibility of totalitarian legal thought with institutions of private ordering is perhaps no mere coincidence. ${ }^{56}$

54 Raz, Freedom, supra note 9, at 385-90, 407-12; Robert P. George, Making Men Moral: Civil Liberties and Public Morality 173-82 (1993).

55 See generally Aquinas, supra note 27, at 1-2; Finnis, supra note 5, at 136-38; JoHN Finnis, Collected Essays of John Finnis, vol. I: Reason in Action 237-43 (Oxford 2012); FinNIs, supra note 28, at 36-39, 83-84.

56 Thus, nongovernmental organizations were invited to participate in Soviet governance as agents of the central powers. Osakwe, supra note 42, at 18. Socialist legal theory took Marxism well beyond Marx, but Krygier persuasively argues that the antipathy of Communist totalitarianism to institutions of private ordering is incipient in Marx's thought.

In Marx's distaste for separateness, boundaries, distinctness, freedom of religion, there is a passion for unmediated social wholeness which, to say the least, has not worn well. In Marx's conception... what was to be liberated in truly human society was the species - from alienation, from self-deception, from dependence on nature and on others, from antagonism, from difference. ... [N]otions of mediating institutions, zones of protected autonomy and plurality, tolerance and protection of individual life plans, simple restraint in the pursuit of huge ambitions, are simply absent from Marx's utopia and would cut deeply against its grain.

Krygier, supra note 34, at 663. In this light, Krygier concludes that the absence of legal securities for mediating institutions in Communist legal thought "was no accident." 
The most blunt and direct way to achieve a monopoly on authority is of course to eradicate, co-opt, or de-legitimize all of the institutions of private ordering, and to kill or ruthlessly oppress anyone who does not go along with the master plan of the central mind. Doing so crushes the souls and suppresses the humanity of the governed by depriving them of the domains, groups, and associations within which they reason together in a fully-human way. That was a favorite path to totalitarian rule in the twentieth century, ${ }^{57}$ and persists in some of the darker corners of the world today, especially North Korea and the Islamic State in Iraq and al-Sham, known as ISIS.

ISIS represents a new form of totalitarianism with perhaps the purest jurisprudence imaginable. The combination of modern weaponry with a fundamentalist jurisprudence grounded in a text that sanctions violence and oppression has produced a state in which all law emanates from a single source-the Caliphate-and even the slightest departures from its rules are deterred. Punishments for disobedience are specific and inhumane. They include beheading, raping, and enslaving. So it is understandable that many people focus on the actions of ISIS. But motivating the violence and degradation is a coherent, if barbaric, jurisprudence that is totalizing in its ambition and apocalyptic in its eschatology. ${ }^{58}$ ISIS does not seek the totalization of legal norms in order to centralize power, it seeks to centralize power in order to purify and totalize all legal norms. It punishes deviations from its rules with the death penalty in order that Islamic law has only one, determinate meaning; "the Quran means exactly one thing, and other levels of meaning or alternate interpretations are ruled out a priori." 59

In other words, the law promulgated by ISIS consists of fully-conclusive, absolute, exceptionless, exclusionary reasons for action. Interestingly, those fully-exclusionary reasons are binding upon everyone, including the ruling elites within ISIS. Unlike Communist rulers who have often acted arbitrarily, the caliph of ISIS, Abu Bakr al-Baghdadi, understands himself to be obligated to obey a particular interpretation of Sharia law. Totalization of all norms and institutions is not a means to an end, it is the end itself. The reason for ISIS to exist is to impose one law on everyone within ISIS, top to bottom, and everyone who comes under its control.

57 See, e.g., Richard Pipes, Human Nature and the Fall of Communism, 49 Bulletin of the American Academy of Arts \& Sciences 38 (1996); Richard Pipes, Property and FREEDOM 209-25 (1999).

58 See Graeme Wood, What ISIS Really Wants, The AtLantic (Mar. 2015) available at http:// www.theatlantic.com/magazine/archive/2015/03/what-isis-really-wants/384980/.

59 Caner K. Dagli, The Phony Islam of ISIS, The AtLantic (Feb. 27, 2015) available at $\mathrm{http} / / / \mathrm{www}$. theatlantic.com/international/archive/2015/02/what-muslims-really-wantisis-atlantic/386156/. See also Jeffrey Goldberg, "Crimes" Jihadists Will Sentence You to Death For, The Atlantic (Nov. 14, 2015) available at http://www.theatlantic.com/ international/archive/2015/11/paris-attacks-isis/415998/. 


\section{Tactical Totalization}

Yet eliminating private law is a useful tactic even when it is not itself a political power's strategic goal. It has proven effective at enabling many projects of social engineering. Governing elites in liberal democracies have ways of eliminating whole categories of private law in broad daylight. These methods leave the forms of institutional autonomy in place but eliminate their authority over important areas of civic life. Two of them have proven popular in recent decades. One, by depriving a community or institution of its sources of authoritative reasons-purpose, conscience, tradition, sacred texts, promises, law-one can deny it the raw materials it needs to order its affairs independently of the collective will. Two, by answering all of a community's practical questions on its behalf, a regime can deprive that community or institution of opportunities to exercise deliberation and judgment.

I will call these practices tactical totalization. Identifying and naming the phenomenon suggests where it might be observed in liberal democracies, and shows how it differs from totalitarian legal ambition. As Martin Krygier observes, no parallel to the "systemic purposefulness" of Communist totalitarianism can be found in liberal democracies. ${ }^{60}$ In liberal democracies, particularly where the common law tradition is intact, we take for granted that law limits power, constrains government, and secures liberty. Underlying the rule of law, so foreign to the experience of those who live in totalitarian states, is "a widespread assumption within the society that law matters and should matter." 61

Nevertheless, this assumption is expensive and fragile. As Krygier observes, it has grown in Western societies over centuries. Experience shows that it cannot be decreed, and that it can be destroyed easily. Thus, we should not allow reified distinctions between totalitarianism and liberal democracy to conceal the possibility of totalization. Totalization of legal norms does occur in liberal societies. It might seem to arise democratically because it arises bloodlessly. However, upon closer examination it seems to emanate not from democratic self-governance, but rather from central authorities of public law, albeit in the name of, or on behalf of, democratic notions such as equality.

One might view totalization in liberal societies as a jurisprudential feature of the political pathology that Alexis de Tocqueville predicted would afflict the United States in its later years, what he called "soft despotism," a new tyranny that grows out of the American commitment to radical equality. In the new age of "enlightenment and equality... rulers could more easily manage to gather all public powers into their own hands and to intrude further and more regularly into the realm of private interests than was ever

\footnotetext{
60 Krygier, supra note 34, at 635.
}

${ }^{61} I d$. at 646 (emphasis in original). 
possible for any ancient sovereign." The "same equality which fosters despotism also tempers it." As fortunes are smaller, imagination is restricted, and pleasures become simpler, the "universal moderation" within democracies would control the ruler's excesses and constrain the "disorderly surges of his desires within certain limits." But the ruler will stand above the masses nonetheless, "an immense and protective power" who seeks not "to prepare men for manhood" but rather "to keep them in perpetual childhood." The governing power is happy to remove from the subjects entirely "the bother of thinking and the troubles of life" and to replace those with "a network of petty, complicated, detailed, and uniform rules." 62

Tocqueville saw "quite clearly that, in this way, individual intervention in the most important affairs is preserved but it is just as much suppressed in small and private ones." ${ }^{33}$ As opportunities for private ordering are eliminated, the citizens are infantilized. The new despotism "reduces daily the value and frequency of the exercise of free choice; it restricts the activity of free will within a narrower range and gradually removes autonomy itself from each citizen" so that all are eventually reduced to "a flock of timid and hardworking animals with the government as shepherd." ${ }^{64}$ Soft despotism thus totalizes the community's norms and subdues its people without the executions, famines, and social disruptions associated with Soviet totalitarianism.

On the other hand, soft despotism has some rather hard edges of its own. Segregationists used tactical totalization in liberal societies in the twentieth century. Unlike totalitarians, they did not abolish religion or private property, nor socialize the means of production. The project of racial segregation was not to bring all of society under a single power for all purposes. Rather, it was to force an implausible conception of equality upon everyone, using public law to make segregation a condition of participation in civic life. Segregationists needed to ensure that every question of interaction between the races was resolved by a single answer. They succeeded as long as they eliminated all norms other than the one norm preferred by the state. Indeed, civil disobedience has proven fatal to segregationist regimes

62 Tocqueville, supra note 1, at 803-09.

63 Id. at 807.

64 The consequences that Tocqueville anticipated are worth considering at length.

[T] he ruling power, having taken each citizen one by one into its powerful grasp and having molded him to its own liking, spreads its arms over the whole of society, covering the surface of social life with a network of petty, complicated, detailed, and uniform rules through which even the most original minds and the most energetic of spirits cannot reach the light in order to rise above the crowd. It does not break men's wills but it does soften, bend, and control them; rarely does it force men to act but it constantly opposes what actions they perform; it does not destroy the start of anything but stands in its way; it does not tyrannize but it inhibits, represses, drains, snuffs out, dulls so much effort that finally it reduces each nation to nothing more than a flock of timid and hardworking animals with the government as shepherd.

Tocqueville, supra note 1 , at 806 . 
when it has appealed to rights and duties that did not owe their existence to the state.

Though tactical totalizers do not control society as comprehensively as strategic totalitarians, they can afford to leave no domain of life beyond the reach of public law. Private ordering in general, and private laws in particular, often prove resistant to a state-approved project. Private law enables whites to give or to sell their title to blacks, or to vest easements, licenses, bailments, and other private rights in their black neighbors, and vice versa. Therefore, a state that is committed to segregation must either eradicate those powers of the sovereign owner or direct their exercise. Private law enables blacks and whites to worship together, to collaborate in business, to learn in the same classrooms. The rights and duties behind which those interactions are possible pose an existential threat to segregation.

During Jim Crow, public law institutions masked their violence to private ordering by retaining the forms and names of the private rights and duties that they had subverted. So, private law was not often a collaborator in Jim Crow. Rather, it was thrice a victim. First, the reasoned judgments it contained were denied juridical enforcement. Second, its emptied form was filled with public rules of forced segregation. Third, it was blamed for the offenses of the public-law authorities who used its name and authority to achieve their unjust ends.

To take a prominent example, property law has long prohibited racial discrimination in public accommodations where race is irrelevant to the purpose for which the property is held open to the public. An owner of a private residence can exclude anyone for any reason, or no reason. An owner who opens his land to the public, say as a pub or a bakery, may only exclude for valid reasons. ${ }^{65}$ And the racial identity of the would-be licensee is not a valid reason. Thus, positive enactments that codify prohibitions against racial discrimination in public accommodations are declaratory of the common law that preceded their enactment. ${ }^{66}$

During Jim Crow, segregationist states produced judicial decisions permitting segregation and enacted statutes requiring racial segregation in public accommodations. The resulting rules have been called "property" laws, though they were really posited rules of public law. Apparently, this practice was not unique to the United States. One scholar of South African law has summarized, "In its dynamic mode apartheid law treated land and land rights as instruments for social change--individual rights were subjected to large-scale state interferences for the sake of building the dream, establishing the 'colossal social experiment' that was apartheid." 67 That social experiment required destruction of private law's content, be-

653 Blackstone, supra note 7, at 212.

${ }_{66}$ Coger v. Northwestern Union Packet Co., 37 Iowa 145 (1873); Ferguson v. Gies, 46 N.W. 718, 719, 720 (Mich. 1890).

67 A.J. Van Der Walt, Dancing with Codes--Protecting, Developing and Deconstructing Property Rights in a Constitutional State, 118 South African L. J. 258, 268 (2001). 
cause private rights and duties are settled and specified by agents and institutions beyond the state's control. But it was useful to co-opt the forms of private law in order to co-opt the authority of private institutions.

In the United States the ruse was largely effective. For example, the failure to identify and distinguish private rights and duties has caused confusion about the nature of the dispute in Shelley $v$. Kraemer. ${ }^{68}$ Herbert Wechsler and Robert Bork criticized the Shelley decision on the ground that it compromises constitutional principles of neutrality. ${ }^{69}$ Like other non-neutral constitutional decisions, the argument goes, Shelley reduces constitutional adjudication to the preferences of judges concerning which actions are legally unacceptable. If any judicial enforcement of a private choice constitutes state action then any private choice becomes a matter of constitutional concern. But post-Shelley constitutional doctrine arbitrarily picks out those private choices that involve racially-discriminatory motives and leaves alone other private choices that would also be constitutional violations if they were state action.

Bork illustrated his concern by imagining a houseguest who "becomes abusive about political matters and is ejected by his host," and then sues his host in state court and loses. ${ }^{70}$ Bork worried that, on the authority of Shelley, the state court judgment against the rude guest must be construed as state action, requiring the Supreme Court to act as rule-maker for all conduct by private individuals on private property. The only way to avoid that result, Bork thought, would be to import into constitutional law "qualifications and limits that themselves have no foundation in the Constitution or the case." ${ }^{71}$ He concluded, "Shelley was a political decision. As such, it should have been made by a legislature."72

Yet, Shelley was decided on the basis of law. As Matthew Franck has observed, the neighbors in the Shelley case were asking a court to deprive the Shelleys, the black homebuyers who took possession of the house on Labadie Avenue, of their vested title. By contrast, no one has a right "to make oneself a nuisance to one's hosts." 73 Put in property terms, vested title in fee simple is a fully-specified, in rem right, good against the world. By contrast, a license to visit the home of a neighbor is not a property right at all. It is fully revocable at the pleasure of the host, and in any event does not entail the right to make unreasonable uses.

68334 U.S. 1 (1948).

69 Herbert Wechsler, Toward Neutral Principles of Constitutional Law, 73 Harv. L. REV. 29 (1959); Robert H. Bork, Neutral Principles and Some First Amendment Problems, 47 Ind. L. J. 1, 15-16 (1971) [hereinafter Neutral]; Robert H. Bork, The Tempting of AMERICA 151-53 (1990) [hereinafter Tempting].

70 Bork, Tempting, supra note 69, at 152.

71 Id. at 153 .

72 Id.

73 Matthew J. Franck, The Last Justice Without a Theory: Fred M. Vinson in SoBER AS A Judge: The Supreme Court and Republican Liberty 121-74, 168 (Richard G. Stevens \& Matthew J. Franck eds., 1999). 
The Shelleys took lawful title to the contested residence when Fitzgerald, their predecessor-in-title, exercised his power of alienability to deliver to them a warranty deed. Their new neighbors on Labadie Avenue in St. Louis then asked the courts of Missouri to give equitable enforcement to a written agreement, which most, but not all, of the homeowners had signed and recorded, prohibiting for a period of 50 years any possession of the residences by "any person not of the Caucasian race." 74 The case therefore presented as a conflict between a delivered deed, conveying lawful title, and a private contract, unenforceable against the third-party Shelleys. This was a no-brainer. The Shelleys were entitled to prevail on straightforward application of private law doctrines.

Shelley is mistakenly known as a case about the enforceability of private real covenants, instruments by which vested property rights are created. Chief Justice Vinson gave credence to this view with his rather imprecise introduction of the case. His opinion for the court opened,

These cases present for our consideration questions relating to the validity of court enforcement of private agreements, generally described as restrictive covenants, which have as their purpose the exclusion of persons of designated race or color from the ownership or occupancy of real property. ${ }^{75}$

It is understandable that Vinson's reference to "covenants," the purpose of which is to govern "occupancy of real property," would mislead. But in fact, there was no real covenant to enforce, only a contract. And the Shelleys were neither contracting parties nor third-party beneficiaries of the contract. No vested rights were at stake other than the title of which the Missouri courts intended to divest the Shelleys.

It is true that the Missouri Supreme Court had enforced the restrictive agreement as a real covenant, but that court simply got the law of covenants wrong. The common law doctrine, followed in Missouri, requires some common nexus of title between covenanters, known as horizontal privity, without which the burden of the covenant cannot run with the land. ${ }^{76}$ The Missouri courts failed to acknowledge that this agreement failed to run to successors-in-title for lack of horizontal privity. Fitzgerald, who sold to the Shelleys, was not a party to the original agreement, but rather was "a white person who was a straw party," transaction for purposes that are not difficult to infer. Because the parcels had no nexus of title at the time of the original agreement they could not run against successors in title to the burdened residence. Fitzgerald, being a successor-in-title, was free and clear of any legal obligation arising out

74 Shelley v. Kraemer, 334 U.S. 1, 4-5 (1948).

75 Id. at 4.

76 Allen v. Kennedy, 2 S.W. 142, 143 (Mo. 1886); Iowa Loan \& Trust Co. v. Fullen, 91

S.W. 58 (Mo. Ct. App. 1905).

77 Kraemer v. Shelley, 198 S.W.2d 679, 680 (Mo. 1946). 
of the agreement. Had he even been a party to the lawsuit, the neighbors would have had no rights against him, much less to the Shelleys, to whom he had already made conveyance.

Kraemer and the other neighbors convinced the Missouri Supreme Court to order the chancellor to enforce the unenforceable covenant with injunctive relief, which would have resulted in the eviction of the Shelleys and their loss of title, and to retain jurisdiction over the case to ensure implementation of the injunction. In doing so, they successfully implicated the Missouri courts in unlawful action in two ways. First, they convinced the Missouri Supreme Court to divest the Shelleys of a vested, legal right by way of equitable relief. Equitable enforcement would clearly have violated equal protection because it would have entailed undoing what law required, and doing so on the ground that the Shelleys were not of the Caucasian race.

Second, the Kraemers implicated the Missouri courts in enforcing a covenant that would not have been enforced as a matter of neutral property doctrine. As a matter of established private law doctrine, the promise did not run with title. There simply was no private right to enforce, apart from the Shelleys' vested dominion over the residence they had purchased from Fitzgerald.

As Franck points out, Chief Justice Vinson, the author of the Shelley decision, clarified Shelley's reach in his dissent from a later decision of the Court, Barrows v. Jackson. ${ }^{78}$ Vinson distinguished Shelley from Barrows on the ground that "in the Shelley case, it was not the covenants which were struck down but judicial enforcement of them against Negro vendees." 79 By contrast, in Barrows the "majority identifies no non-Caucasian who has been injured or could be injured if damages are assessed against respondent for breaching the promise which she willingly and voluntarily made to petitioners, a promise which neither the federal law nor the Constitution proscribes." ${ }^{80}$ Vinson's dissent clarified the imprecision in his Shelley opinion. Shelley involved unsettling a vested right by means of a contract that was unenforceable in property law. The claim right and no-right settled by property law both favored the Shelleys. Shelley was not a case about state courts vindicating lawful private covenants in violation of the Equal Protection clause of the Fourteenth Amendment, as if what is lawful in common law is unlawful in constitutional law.

In Barrows, by contrast, the covenant was enforceable. Horizontal privity was not required because the defendants were the original covenanting parties. So the agreement breached was a straight-forward contract, with a detestable but not criminally-prohibited or otherwise unlawful consideration. No one was deprived of any vested property rights.

78346 U.S. 249 (1953).

79 Barrows v. Jackson, 346 U.S. 249, 261 (1953) (Vinson, C.J., dissenting).

$80 \quad$ Id. at 262. 


\section{TACTICAl TOTAlization TODAY}

The elimination of private law and its plural goods from consideration in deciding important legal questions is an animating impulse of many governing elites today. ${ }^{81}$ In contemporary democracies, the totalization of law is not attended by mass slaughter or famine, as it was in twentieth-century Nazi and Communist totalitarian regimes. Tactical totalization of law does not produce such dramatic, immediate carnage. Instead, the consequences unfold more slowly.

\section{A. Totalization There}

The shift from strategic totalitarianism to tactical totalization might be perceived in China. China has grown more open in some ways; it recently amended its one-child policy to permit couples to have two children. ${ }^{82}$ Yet the government exercises authoritarian control over wide swaths of Chinese society through detailed rules promulgated by centralized authorities. To justify the removal of crosses and other public displays of Christian religious identity, even the demolition of churches, Chinese officials have resorted to land use regulations. ${ }^{83}$ Zoning restrictions are used as a means of lowering the civic profile of Christian institutions, ${ }^{84}$ whose commitment to natural law and intrinsic human worth are perceived as threats to the totalizing ambitions of government. A New York Times article reports, "Some Chinese Protestants

81 A clear articulation of the totalizing impulse is a recent book arguing, without any apparent sense of irony, that a "tolerant-liberal democracy should be reluctant to tolerate religious claims for accommodation" and for "conscientious exemptions from legal norms." Yossi Nehushtan, Intolerant Religion in a Tolerant-Liberal Democracy 1 (2015) Tolerance destroys itself in its quest to eliminate that which it deems intolerant.

82 Steven Jiang \& Susannah Cullinane, China's One-Child Policy to End, CNN (Oct. 30, 2015) available at http://www.cnn.com/2015/10/29/asia/china-one-child-policy/index. html.

83 Michael Forsythe, Chinese Province Issues Draft Regulation on Church Crosses, N. Y. TIMEs (May 8, 2015) available at; Congressional-Executive Commission on China, Zhejiang Government Launches Demolition Campaign, Targets Christian Churches (June 6, 2014) available at http://www.cecc.gov/publications/commission-analysis/ zhejiang-government-launches-demolition-campaign-targets-christian; Rachel Ritchie, Zhejiang authorities propose regulations prohibiting cross displays on churches' roofs; more than 10 crosses removed, China Aid (May 7, 2015) available at http:// www.chinaaid.org/2015/05/zhejiang-authorities-propose_7.html; Christian Solidarity Worldwide, Zhejiang Church Demolitions: Timeline of Events, available at http://www. chinaaid.org/2015/05/zhejiang-authorities-propose_7.html.

84 Ian Johnson, Church-State Clash in China Coalesces Around a Toppled Spire, N. Y. Times (May 29, 2014) available at http://www.nytimes.com/2014/05/30/world/asia/ church-state-clash-in-china-coalesces-around-a-toppled-spire.html?_r=1. 
argue that rights such as freedom of expression are God-given, and thus cannot be taken away by the state. These beliefs have led many Protestants to take up human rights work. A disproportionate number of lawyers handling prominent political cases, for example, are Protestant [Christians]." ${ }^{85}$ Chinese officials thus find it expedient to make Christians less visible, and find land use regulations convenient means of doing so.

In Western Europe one sees the totalizing impulse in the recent effort to criminalize male circumcision, ${ }^{86}$ which failed, ${ }^{87}$ and in efforts to eradicate home schooling, which have largely succeeded. ${ }^{88}$ The German government imposes chilling penalties upon families who attempt to educate their own children without the state's control, ranging from fines to taking away custody of the children. ${ }^{89}$ The express motivation for this effort is to eradicate domains of private ordering within which religious communities and families can constitute themselves consistent with their convictions. ${ }^{90}$ The German high court declaimed the German government's totalizing motivation outright, stating "that the purpose of the German ban on homeschooling was to "counteract the development of religious and philosophically motivated parallel societies." 91

China and Germany of course have totalitarian histories. But even societies with long-standing traditions of ordered liberty today are prone to tactical totalization. In the land of Magna Carta, Members of Parliament have recently moved to prohibit some testators from devising and bequeathing their property in accordance with their religious convictions; they promised to open a joint investigation by the Commons Justice and Home Affairs Committees into the use of religious law to undermine equality rights. A headline in the Telegraph misleadingly hyperventilated, "Islamic Law is Adopted by British Legal Chiefs," and contained various references to the potential con-

85 Id.

86 Kharunya Paramaguru, German Court Bans Male Circumcision, Time (June 29, 2012), available at http://newsfeed.time.com/2012/06/29/german-court-bans-male-circumcision/.

87 John MacDougall, Circumcision to Remain Legal in Germany, NBC News (Dec. 12, 2012), available at http://worldnews.nbcnews.com/_news/2012/12/12/15869347-circumcision-to-remain-legal-in-germany.

88 Michael Steininger, Where Homeschooling is Illegal, BBC News (Mar. 22, 2010), available at http://news.bbc.co.uk/2/hi/uk_news/education/8576769.stm.

89 Id.

90 An American lawyer involved in litigation on behalf of German families explains, Germany does permit some people to homeschool, but it is rare and in general Germany does ban homeschooling broadly - although not completely. (Germany allows exemptions from compulsory attendance for Gypsies and those whose jobs require constant travel. Those who want to stay at home and teach their own children are always denied.)

Michael Farris, German Homeschool Case May Impact U.S. Homeschool Freedom, Home School Legal Defense Association (Feb. 11, 2013), available at http://www.hslda.org/docs/news/2013/201302110.asp.

91 Id. 
flicts between Sharia and comprehensive equality laws. ${ }^{92}$ The reason for this mobilization of legislative power was that the Law Society had issued a practice note instructing solicitors on how to draw up wills that effectuate their clients wishes, as the common law has long provided. ${ }^{93}$

Many Muslims are bound in conscience to dispose of their assets in obedience to Sharia, which differentiates between Muslim and non-Muslim practices. These dispositions are not unlawful; they do not involve honor killings, forced marriages, or criminal acts. (These Muslims are not ISIS.) The norms governing the dispositions give preference to religious observance over nonobservance, marriage over divorce, and traditional distributions of resources between men and women. Women get smaller elective shares, but are entitled to keep their own property separate and to require payment of a marriage gift, while men's property is for the communal use of the family. ${ }^{94}$ Thus, inheritance under Sharia is determined by the heir's financial obligations.

To be sure, some radical strains of Islam are totalitarian and oppressive (see ISIS). However, allowing peaceful Muslims to obey their consciences without committing malum in se offenses is not endorsing oppression or even their beliefs. Enforcing the wills of religious testators in court would not entail endorsing the judgments of religious tribunals or arbitration authorities, ${ }^{95}$ nor would it entail giving effect to the laws of any other states, ${ }^{96}$ or involve British courts in sanctioning criminal or wrongful acts. Instead, Parliament is gearing up to eliminate this domain of private ordering lest devout Muslims in the course of making their testamentary dispositions distinguish between men and women, marriage and non-marriage, Muslim observance and infidelity.

Or consider Canada. Nine years ago, Ontario outlawed religious arbitration. In a perfectly succinct statement of tactical totalization, the Ontario premier insisted that there is only "one law for all Ontarians." ${ }^{97}$ More

92 John Bingham, Islamic Law is Adopted by British Legal Chiefs, Telegraph (Mar. 22, 2014) http://www.telegraph.co.uk/news/religion/10716844/Islamic-law-is-adoptedby-British-legal-chiefs.html

93 The Law Society, Sharia Succession Rules (Mar. 13, 2014), available at http://www. lawsociety.org.uk/advice/practice-notes/sharia-succession-rules/.

94 Id. at §3.6; Omar T. Mohammedi, Sharia-Compliant Wills: An Overview, 25 Probate \& PROPERTY 58, 60-62 (2011).

95 Contrast the anti-Sharia laws discussed in John Witte, Jr. \& Joel A. Nichols, Who Governs the Family?: Marriage as a New Test Case of Overlapping Jurisdictions, 2 FAULKNER L. Rev. 321 (2013).

96 The effort to prohibit enforcement of these wills is an even more straight forward attack on private law and religious exercise than laws which prohibit courts from giving effect to Sharia law or the laws of nations governed by Sharia. Oklahoma's attempt to enact such a law was struck down for its infringement of religious freedom under the Establishment Clause of the First Amendment to the United States Constitution. Awad v. Ziriax, 670 F.3d 1111 (10 $10^{\text {th }}$ Cir. 2012).

${ }_{97}$ Sharia Law Move Quashed in Canada, BBC News (Sept. 12, 2005) http://news.bbc. co.uk/2/hi/americas/4236762.stm. 
recently, Trinity Western University in British Columbia proposed to open a law school. Trinity Western is affiliated with the Evangelical Free Church, a Protestant denomination whose teachings "are formed by a firm commitment to the person and work of Jesus Christ as declared in the Bible." Its administrators, faculty, staff, and students voluntarily promise "to live according to biblical precepts," which include honoring in all persons "their God-given worth from conception to death"; "exhibiting honesty, civility, truthfulness, generosity and integrity"; respecting authority and obeying the law; avoiding divorce; and reserving "sexual expressions of intimacy for marriage," defined as the union of a man and a woman. ${ }^{98}$

After performing extensive due diligence and making the necessary proposals and applications, Trinity Western obtained certification from the relevant education ministries and accreditation from the British Columbia Law Society. ${ }^{99}$ Then, the law societies of Ontario and Nova Scotia voted to deny to graduates of Trinity Western's law school admission to the bar. For the future offense of promising to live biblically, all hypothetical prospective graduates of Trinity Western's not-yet-existent law school have already been deemed ethically unsound ${ }^{100}$ and, therefore, unworthy of entrance into the legal profession. Then, bowing to political pressure, and in spite of a 2001 decision of the Supreme Court of Canada ruling that Trinity Western has the right to operate a school of education, ${ }^{101}$ the British Columbia Law Society and Education Minister reversed their earlier decisions to allow Trinity Western's law school to proceed. ${ }^{102}$

Now Trinity Western's law school is fighting for the right to exist. ${ }^{103}$ The Attorney General of Canada has opined that the Supreme Court of

98 Trinity Western University, Community in Covenant: Our Pledge to One Another, https:// twu.ca/studenthandbook/university-policies/community-covenant-agreement.html

99 Voting to Accredit: Excerpts from the BC Benchers Meeting, TWU Law School Blog, available at http://twulawschool.tumblr.com/post/87994320852/voting-to-accreditexcerpts-from-the-bc-bencher.

${ }^{100}$ Charlotte Santry, Ontario Lawyers Weighing in on Trinity Western, Law Times (Mar. 31, 2014), available at http://www.lawtimesnews.com/201403313881/headline-news/ ontario-lawyers-weighing-in-on-trinity-western.

101 Trinity Western Univ. v. B. C. College of Teachers, 1 S.C.R. 772, 2001 SCC 31. (2001)

${ }^{102}$ Trinity Western Law School: B.C. Advanced Education Minister Revokes Approval, CBC News, (December 11, 2014), available at http://www.cbc.ca/news/canada/british-columbia/trinity-western-law-school-b-c-advanced-education-minister-revokesapproval-1.2870640.

103 The Canadian Press, Trinity Western law school accreditation denial upheld by Ontario court, CBC News (July 2, 2015) available at http:/www.cbc.ca/m/news/canada/ british-columbia/trinity-western-law-school-accreditation-denial-upheld-by-ontariocourt-1.3136529; The Canadian Press, Law society in Nova Scotia appealing ruling in favour of Trinity Western, CBC News (Mar. 24, 2015) available at http://www.cbc.ca/ news/canada/nova-scotia/law-society-in-nova-scotia-appealing-ruling-in-favour-of-trinity-western-1.3006646. 
Canada vindicated that right in its 2001 decision, ${ }^{104}$ but Trinity Western must litigate again to preserve it. Even accounting for the unwillingness of many to accept the rationality of the Christian distinction between sexual desires and sexual conduct, it is difficult to understand the hostility to Trinity Western as anything other than totalization. Trinity Western welcomes students with same-sex attraction who want to study at a Christian university. ${ }^{105}$ Alumni of Trinity Western's undergraduate colleges who made the same promise to live biblically have succeeded in other law schools in Canada $^{106}$ and are contributing to the Canadian legal profession, even in Canada's Parliament. ${ }^{107}$ The logic of the movement against Trinity Western is not to preserve the competence of the legal profession, but rather to strangle in the crib, an institution whose members voluntarily choose to live according to Christian convictions.

\section{B. Totalization Here}

Here in the United States, the prognosis for private law is mixed. The domain of national, public law has expanded enormously. A recent Federalist Society symposium asked, "Is there any area of modern life to which federal government power does not extend?" 108 It appears that the search for that area is ongoing, but that the mission has shifted from its rescue to its recovery stage.

On the other hand, in the last few terms the Supreme Court has strengthened the autonomy of institutions of private ordering. It has upheld the rights of property owners to be protected against regulatory takings, ${ }^{109}$ has re-affirmed the autonomy of religious institutions to make their own personnel decisions under the ministerial exception to non-discrimination

${ }^{104}$ Brief of the Intervenor, The Attorney General of Canada, Trinity Western University v. Nova Scotia Barrister's Society, Supreme Court of Nova Scotia No. 427840, available at http://nsbs.org/sites/default/files/ftp/TWU_Submissions/AttorneyGeneralCanada 07-11-2014.PDF.

${ }^{105}$ Dear Trinity, I'm Gay and I Love You, TWU Alumni Association, available at http:// twualumni.org/column/dear-trinity-im-gay-love/.

106 Jesse Legaree, Dear Nova Scotia Human Rights Commission: what's best for me is real freedom, TWU Law School Blog, available at http://twulawschool.tumblr.com/ post/105887907117/dear-nova-scotia-human-rights-commission-whats.

${ }^{107}$ Lorna Dueck, Trinity Western Affair a Trial of Canadian Civility and Tolerance, The Globe and Mail (Dec.11, 2014), available at http://www.theglobeandmail. com/globe-debate/trinity-western-affair-a-trial-of-canadian-civility-and-tolerance/ article22041303/?cmpid=rss1\&utm_source=twitterfeed\&utm_medium=twitter.

108 Title Page, 37 Harv. J. L. \& Pub. Policy i (2014).

109 Arkansas Game \& Fish Comm'n v. United States, 133 S. Ct. 511, 184 L. Ed. 2d 417, 75 ERC 1417 (2012); Koontz v. St. Johns River Water Mgmt. Dist., 133 S. Ct. 2586, 186 L. Ed. 2d 697 (2013). 
laws, ${ }^{110}$ and has recognized an implied right of private landowners to have the factual findings of regulatory agencies reviewed by a court of law. ${ }^{111}$

These developments signal the Court's increased sensitivity to (at least some) private rights and duties. But do they matter in light of public law's ambitious expansion project? If there is no jurisprudential question which public law is willing to leave unanswered then to preserve the autonomy of private law makers is to award them a pyrrhic victory. Institutions of private ordering are permitted freedom to deliberate and to exercise judgment... but about what?

Not only the ambitions of the regulatory state, but also those of courts ratifying individual right claims, can jeopardize private law. The invention of novel, uniform, and individualized constitutional rights is just as useful to tactical totalizers as the expansion of the Code of Federal Regulations. Abstract rights which have no foundation in natural law, the common law, private law, custom, or usage, must necessarily deprive institutions of private ordering of their jurisdiction over whole categories of human affairs.

Tactical totalization is a standing temptation for governing powers on both the left and the right. ${ }^{112}$ To put it in concrete terms, deference to private law would caution against the individual mandate of the Affordable Care Act, ${ }^{113}$ the abortifacient mandate of the Department of Health and Human Services, ${ }^{114}$ and the ruling of the Supreme Court in Snyder $v$. Phelps, ${ }^{115}$ which began as an action sounding in tort. ${ }^{116}$ Phelps and other protestors from the so-called Westboro Baptist Church turned the funeral of Marine Lance Corporal Matthew Snyder into a publicity stunt when they descended upon it with signs reading "Thank God for dead soldiers,"

${ }^{110}$ Hosanna-Tabor Evangelical Lutheran Ch. \& Sch. v. EEOC, 132 S. Ct. 694, 181 L. Ed. 2d 650, 114 FEP Cases 129, 25 AD Cases 1057 (2012).

111 Sackett v. EPA, 132 S. Ct. 1367 (2012).

112 Robert Bolt's play, A Man For All Seasons, puts in the mouth of Thomas More an admonition to his son-in-law, William Roper, that would-be totalizers would do well to heed, no matter how righteous the ends they are pursuing.

"ROPER: So now you'd give the Devil benefit of law! MORE: Yes. What would you do? Cut a great road through the law to get after the Devil? ROPER: I'd cut down every law in England to do that! MORE: Oh? And when the last law was down, and the Devil turned round on youwhere would you hide, Roper, the laws all being flat? This country's planted thick with laws from coast to coast -man's laws, not God's - and if you cut them down - and you're just the man to do it — d'you really think you could stand upright in the winds that would blow then? Yes, I'd give the Devil benefit of law, for my own safety's sake.."

Robert Bolt, A Man for All Seasons 66 (1960).

11326 U.S.C. § 5000a. See National Federation of Independent Business v. Sebelius, 132 S. Ct 2566 (2012).

11478 FR 39869 (2013). See Burwell v. Hobby Lobby Stores, Inc., 573 U.S. (2014).

115131 S. Ct. 1207, 179 L. Ed. 2d 172 (2011).

116 Snyder v. Phelps, 533 F.Supp.2d 567 (D. Maryland 2008). 
"You're going to Hell," "God hates you," and "Semper Fi Fags." ${ }^{117}$ Before the funeral they issued a press release and notified police officials of their intentions in order to attract media attention. ${ }^{118}$

After hearing this evidence, a jury determined that Phelps and his fellow protestors should be held liable for intentional infliction of emotional distress and invasion of privacy, established tort doctrines with specific elements. ${ }^{119}$ In setting this verdict aside, the Supreme Court did not determine that the evidence was sufficient to support it. Instead, it ruled that the jury must not be allowed to pass judgment upon Phelps' conduct, lest its verdict suppress other, caustic and outrageous expressions that might interest the public. ${ }^{120}$ Even within the sacred domain of a funeral, public law will insert itself to ensure "breathing space" for political expressions. ${ }^{121}$

With this novel constitutional right afoot, no domain is sacred from the intrusions of politics. After Snyder $v$. Phelps, if the speaker pronounces on a matter of public interest then the speaker transforms the private domain into one governed by public law, and neutrality requires that the political expression must prevail over the private domain, no matter how vulgar the speech is, and even when it is pronounced at what would have been a private funeral but for the speaker's mischief.

This rule of putative neutrality is the Court's own invention. The text of the First Amendment is silent on the question whether wrongful conduct can ever constitute protected speech. And before the Court's 1964 decision in New York Times v. Sullivan, ${ }^{122}$ the Court had ruled on various occasions that tortious expressions are not entitled to First Amendment protection. ${ }^{123}$ But, in the three years between the last of those decisions and its decision in Sullivan, the Supreme Court lost its attention to the primary role of private law in specifying the rights and duties secured by the First Amendment's speech clause.

In Sullivan, a state court judge in Alabama had not-so-subtly directed a jury to make a half-million dollar punitive damages award to a city commissioner against the New York Times for false statements that it had published about Montgomery, Alabama police. ${ }^{124}$ This involved a distortion of the common law doctrine of libel per se, which allows a claimant's cause of action to proceed if the defamatory statement concerns his business or

\footnotetext{
117 Id. at 569-70.

$118 \mathrm{Id}$. at $571-72$.

119 Id. at 573.

120 Snyder v. Phelps, 131 S. Ct. at 1219.

121 Id.

122376 U.S. 254 (1964).

123 Konigsberg v. State Bar of California, 366 U.S. 36, 49, and n. 10 (1961); Times Film Corp. v. City of Chicago, 365 U.S. 43, 48 (1961); Roth v. United States, 354 U.S. 476, 486-487 (1957); Beauharnais v. Illinois, 343 U.S. 250, 266 (1952); Pennekamp v. Florida, 328 U.S. 331, 348 —349 (1946); Chaplinsky v. New Hamphire, 315 U.S. 568, 572 (1942); Near v. Minnesota, 283 U.S. 697, 715 (1931).

124 Sullivan, 376 U.S. at 262--63.
} 
profession. ${ }^{125}$ By invoking this doctrine, the Alabama courts were able to remove the question from the province of the jury with no evidence of actual injury to Sullivan, even though Sullivan was not named in the libelous publication. ${ }^{126}$ The trial judge also wrongly excused Sullivan from his burden of showing intent. ${ }^{127}$

In short, tort law did not support the segregationists, and we will never know what the jury might have ruled had it not been misdirected. The Alabama courts distorted private law to suit their goals. To repair this wound in the law would have required the precision of a scalpel. The Supreme Court of the United States instead addressed the wound with the blunt end of a sledgehammer. The Court invented a new right to publish defamatory material unless the claimant can show actual malice, ${ }^{128}$ a nearly impossible burden.

The cultural context in which the Court decided Sullivan-the lawlessness of Southern institutions in the 1960s-might obscure from view the Court's contestable, unstated assumption that it must step in and invent a new constitutional right to correct every unjust ruling by a state supreme court which rests upon an unreviewable distortion of state law. That assumption is of course ridiculous. The Court frequently declines to review egregious state court decisions, and when it does grant review, it stops well short of inventing new constitutional rights to remedy their errors.

If the assumption were true then a case at least as worthy of the Court's intervention can be found in Elane Photography $v$. Willock, ${ }^{129}$ a decision of the New Mexico Supreme Court which the Supreme Court of the United States decided not to hear. ${ }^{130}$ Elane Photography, a small business owned and operated by a Christian couple, the Huguenins, was judged guilty of a human rights offense after declining to photograph a same-sex wedding. ${ }^{131}$ The offense was discrimination on the basis of sexual orientation in a public accommodation, which is prohibited by statute. ${ }^{132}$ However, the judgment against the Huguenins was contrary to the facts because they did not discriminate on the basis of sexual orientation. Rather, they distinguished between relationships that naturally partake of the nature of marriage and those that do not, ${ }^{133}$ a distinction grounded in their religious convictions and public reason, ${ }^{134}$ and one that was affirmed by New Mexico state law,

\footnotetext{
125 Restatement (First) of Torts $\S 569$ (1938).

126 Sullivan, 376 U.S. at 256--63.

127 Id. at 262.

128 Id. at 279--80.

129309 P.3d 53 (2013).

${ }^{130}$ Elane Photography, LLC v. Willock, 134 S. Ct. 1737 (2014).

131 Elane Photography, 309 P.3d at 59--60.

132 Id. at 59.

133 Id. at 59-60, 60-63.

134 For philosophical articulations and defenses of this distinction, see SHERIF GIRGIS, RYAN T. Anderson, \& Robert P. George, What is Marriage?: Man and Woman: A Defense (2012); Patrick Lee \& Robert P. George, Conjugal Union: What Marriage is and Why
} 
which at the time defined marriage as the union of a man and a woman, and by long-standing precedent of the Supreme Court of the United States. ${ }^{135}$

That distinction is found throughout the rights and duties of private law to this day. Even States that redefined marriage years ago to extend legal recognition to same-sex couples, such as Massachusetts and New York, have retained the distinction between natural marriage and samesex marriages for many purposes. Massachusetts, for example, retains the presumption of paternity, ${ }^{136}$ which makes no sense if two men are "married" in the same way as a man and woman. ${ }^{137}$ Recently the high court of New York interpreted New York's incest prohibition in light of its rational basis that incest carries a risk of genetic defects in potential biological offspring. ${ }^{138}$ (The other rational basis for the law is the community's moral "abhorrence," 139 and it is difficult to see how that justification can survive the Supreme Court's ruling in Lawrence v. Texas.) ${ }^{140}$ That rule, too, makes no sense if two men or two women have exactly the same rights and duties of "marriage" as a man and a woman. Surely a business policy that maintains fidelity to the distinction is a good reason for the purposes of public accommodation laws, even one with such totalizing ambitions as New Mexico's.

The right infringements in Elane Photography are manifest. Writing separately in concurrence, one of the justices acknowledged that the $\mathrm{Hu}-$ guenins "now are compelled by law to compromise the very religious beliefs that inspire their lives," but insisted that this is the "price" one must now pay to participate in "civic life" in New Mexico. ${ }^{141}$ The loss of the freedom to constitute oneself, one's relations, and one's privately-owned business in ways that do not directly violate one's own conscience and the "very religious beliefs that inspire" one's own life-the freedom to constitute one's most meaningful identity-is quite a heavy price to pay to ensure that other may constitute their own (sexual) identity on whatever privatelyowned public accommodation they choose.

it Matters (2014). Of course, there are skeptics of this view. Andrew Koppelman, Judging the Case Against Same-Sex Marriage, 2014 U. ILL. L. Rev. 431. And there are replies to these skeptics. Sherif Girgis, Windsor: Lochnerizing on Marriage?, 64 CASE W. Res. L. Rev. 971 (2014).

${ }_{135}$ Baker v. Nelson, 409 U.S. 810 (1972)

136 Massachusetts General Laws c. 209C, § 6.

${ }^{137}$ See generally, Goodridge v. Dept. Public Health, 798 N.E.2d 941, 995-97 (Mass. 2003) (Cordy, J., dissenting).

${ }_{138}$ Nguyen v. Holder, 21 N.E.3d 1017, 1021--22 (N.Y. 2014).

139 Id. at 1021.

140539 U.S. 558 (2003).

${ }^{141}$ Elane Photography, 309 P.3d at 79--80 (Bosson, J., concurring). 


\section{Totalization and the Loss of Private Ordering}

Tactical totalization projects have far-reaching consequences for civic order. The New Mexico Supreme Court's decision in Elane Photography managed to disable two domains of private ordering with one shot-the domain of conscience and the domain of free association within public accommodations. The absence from Elane Photography of a third important private law institution-the civil jury-was not even noticed. Perhaps the most troubling aspect of the case is the consolidated rule-making, fact-finding, prosecutorial, and adjudicatory authority of the New Mexico Human Rights Commission, which acted in the case as lawmaker, advocate, jury, and judge. The delegation of such authority to unelected commissions has become too common in states and nations which used to entrust important factual questions and moral judgments to juries.

These commissions, which are generally comprised of lawyers and other experts, ignore many of the traditional requirements of due process, such as trial by jury, even as they exercise authority to destroy the lives and fortunes of private citizens. Most importantly, they tend to resolve issues with uniform rules that are impervious to the nuanced demands of practical reasonableness. It takes a rather unprecedented fully exclusionary reason to scrub from deliberations the distinction between marriage and non-marriage and the freedom of conscience to discern between them.Surely it is at least sometimes rational to act on that distinction. But the commissions have not allowed it.

Historically, juries have tended to be better grounded in nuance, local context, and common sense. The disappearing role of the jury in ordering our private and civic affairs is a loss for liberty. When empanelled in a civil action, a jury is an important institution of private ordering and private law. The jury's deliberation and judgment are acts of private citizens resolving specific disputes between other private citizens. The jury's verdict is binding upon the parties, not the public at large, and is generally limited to questions of fact, which are not universal but rather peculiar to the case. And juries can inject proportion and common-sense judgment into legal institutions which are badly in need of both.

Snyder v. Phelps, New York Times v. Sullivan, and Elane Photography $v$. Willock can be viewed as victories for liberty only if one believes that citizens should be liberated from the judgments of fellow citizens about what actions are right and wrong. On whole categories of issues jurors, religious observers, and business owners may no longer consider facts or nuance, they may no longer be trusted with the ancient maxims and doctrines of the common law or with conscience, they may not exercise common sense, and under no circumstances may they be allowed to express moral judgment. In short, they may not exercise practical reason to resolve important questions of civic ordering. 


\section{The Possibility of Pluralism}

A silver lining in this cloud is that, unlike strategic totalitarians, tactical totalization leaves the forms of private law concepts and institutions in place, even as it subverts those concepts and institutions for its own ends. The persistence of the forms can lead curious lawyers to wonder where they came from, and what reasons grounded their intelligibility before law was instrumentalized. If we examine them carefully, we might learn something about liberty, pluralism, and the common good.

It is interesting to note that Tocqueville, who predicted the rise of soft despotism, thought it neither possible nor desirable to re-institute aristocracy as a cure for the despotic tendencies of liberal democracies. Instead, he recommended inter alia that powers removed from corporations and nobility be placed in the hands of "secondary bodies temporarily formed of ordinary citizens." 142 He held up the jury, particularly when adjudicating civil cases, as an Anglo-American institution that empowers citizens and is an enemy to those sovereigns who wish to control society. "Juries, especially civil juries, help to instill into the minds of all the citizens something of the mental habits of judges, which are exactly those that best prepare the people to be free." 143

Tocqueville also observed that customs, private ownership, and other common-law sources of legal norms contributed to the healthy self-governance of the American people. He generally subscribed to the view that "associations of ordinary citizens may produce very wealthy, influential, strong people who resemble, in a phrase, aristocratic bodies," and could increase freedom without diminishing equality. ${ }^{144}$

Perhaps even more salutary is that, unlike strategic totalitarianism, tactical totalization is generally deployed on behalf of persons, rather than a collective or abstraction. It is sometimes deployed for bad reasons, as to prevent inter-mixing of races, and sometimes for good, as to secure freedom of political expression, but the justification, however flimsy or admirable, ultimately rests in the rights or ostensible well-being of a person or group of persons. As long as this priority of persons ${ }^{145}$ is preserved, the excesses of tactical totalization can be corrected by reference to the persons harmed by those excesses.

Universalizability of norms entails that our concern for the rights or well-being of one ought to correspond with and be tempered by our concern for the rights and well-being of others. If the justification for a project of totalization is that it will benefit person or group A then we ought to ask whether one can justify the costs it imposes upon person or group B.

\footnotetext{
142 Tocqueville, supra note 1 , at $810-11$.

143 Id. at 320.

${ }^{144} I d$. at 811.

145 On which, see Finnis, supra note 28, at Ch.1; Finnis, supra note 13.
} 
For example, if Vanderbilt University's law school should have the power and liberty to constitute itself by excluding those who do not share its conception of non-discrimination then we might wonder why Trinity Western University's law school should not enjoy the power and liberty to constitute itself by excluding those who would undermine its conception of Christian virtue.

As long as totalization is justified with reference to persons and groups of persons, the justifications offered for projects of tactical totalization contain their own limiting principles. Reinvigorating those principles can promote the common good. Universalizability of norms recommends not a totalizing equality but rather a robust and variegated pluralism. History suggests that where private law flourishes, pluralism flourishes. And there human beings flourish. 
